\title{
Publisher Correction: Analysis and optimization of quantum adaptive measurement protocols with the framework of preparation games
}

\author{
M. Weilenmann (D), E. A. Aguilar (iD \& M. Navascués
}

Correction to: Nature Communications https://doi.org/10.1038/s41467-021-24658-9, published online 27 July 2021.

In the original PDF of this article, figures 4 and 5 were inadvertently omitted. The original article PDF has been corrected. The HTML version was unaffected.

Published online: 14 January 2022

\begin{abstract}
(c) (i) Open Access This article is licensed under a Creative Commons Attribution 4.0 International License, which permits use, sharing, adaptation, distribution and reproduction in any medium or format, as long as you give appropriate credit to the original author(s) and the source, provide a link to the Creative Commons license, and indicate if changes were made. The images or other third party material in this article are included in the article's Creative Commons license, unless indicated otherwise in a credit line to the material. If material is not included in the article's Creative Commons license and your intended use is not permitted by statutory regulation or exceeds the permitted use, you will need to obtain permission directly from the copyright holder. To view a copy of this license, visit http://creativecommons.org/licenses/by/4.0/.
\end{abstract}

(c) The Author(s) 2022 